Please do not remove this page

RMIT

UNIVERSITY

\title{
Innovative Australian public sector construction management: effectively engaging the private sector
}

Thomson, John Douglas

https://researchrepository.rmit.edu.au/esploro/outputs/9921859221701341/filesAndLinks?institution=61RMIT_INST\&index=null

Thomson, J. D. (2012). Innovative Australian public sector construction management: effectively engaging the private sector. Proceedings of the 17th International Symposium on Advancement of Construction Management and Real Estate, 1-11.

https://researchrepository.rmit.edu.au/discovery/fulldisplay/alma9921859221701341/61RMIT_INST:Resea rchRepository

Document Version: Accepted Manuscript

Repository homepage: https://researchrepository.rmit.edu.au

(C) 2012 Chinese Research Institute of Construction Management

Downloaded On 2023/04/26 22:51:16 +1000 
Thank you for downloading this document from the RMIT Research Repository.

The RMIT Research Repository is an open access database showcasing the research outputs of RMIT University researchers.

RMIT Research Repository: http://researchbank.rmit.edu.au/

\section{Citation:}

Thomson, J 2012, 'Innovative Australian public sector construction management: effectively engaging the private sector', in Wang Jiayuan; Ding Zhikun; Zou Liang; Zuo Jian (ed.) Proceedings of the 17th International Symposium on Advancement of Construction Management and Real Estate, United Kingdom, November 16-18, 2012, pp. 1-11.

See this record in the RMIT Research Repository at:

http://researchbank.rmit.edu.au/view/rmit:20078

Version: Accepted Manuscript

Copyright Statement: (c) 2012 Chinese Research Institute of Construction Management

Link to Published Version:

http://www.worldcat.org/oclc/858764077 


\title{
Innovative Australian Public Sector Construction Management: Effectively Engaging The Private Sector.
}

\author{
John Douglas Thomson \\ Graduate School of Business and Law, \\ RMIT University, 405 Russell St, \\ Melbourne, Australia, 3000
}

\begin{abstract}
This research addresses problems where 'poor quality tender documents continue to be a source of inaccurate estimates, claims and disputes' (Laryea, 2011 pps 275-286) and 'few industries suffer more from conflict than construction' (Black et al, 2000). Much of this conflict derives from differing aims - Australian public sector owners aim to achieve 'value for money', while contractors aim to optimize profit and improve reputation. Counter-intuitively, the research found that construction industry experts engaged early assisted in translating owner's needs expression, established and maintained good interface relationships, and moderated contract variations. With period and price fixed, process transparency was improved, tenderers concentrated on submitting innovative 'value for money' offers, tender assessment time and cost were reduced, and the contract completed without dispute. Increased design and construction risk was transferred to and accepted by the Contractor, and provided innovative opportunities pre and post contract award for owner and contractor.
\end{abstract}

Keywords: project planning, construction industry, public sector, innovation, capability. 


\section{Innovative Australian Public Sector Construction Management: Effectively Engaging The Private Sector.}

\section{INTRODUCTION}

The Australian government is the construction industry's largest single domestic client (Love, Niedzweicki, Bullen and Edwards, 2012 p63) and can be 'influential in stimulating innovation' and 'sustainable technologies' (Green and Randles, 2006 in Love et al, 2012 p63). There is a 'growing preference for "performance" vis a vis "prescriptive” based regulations because they encourage innovation' (Gann, Wang, and Hawkins,1998 in Love et al, 2012 p63). The UK National Audit Office (2011) has also identified the need for ongoing public innovation given that 'there are pressing social, demographic and environmental challenges that will demand the development of innovative products, business processes and ways of delivering services'. Mathews, Lewis and Cook (2009 p2) suggest that the 'contemporary public sector management agenda that has been emerging since the early years of the new century seeks to challenge the ethos that the public sector is neither equipped to be nor should seek to become, innovative.' Organization for Economic Cooperation and Development (OECD, 2008) governments are seeking to put into place comprehensive innovation friendly policy stances. In the USA, Stephen Goldsmith, Director of Innovations in American Government Programs at the Harvard Kennedy School states that the innovation process 'cannot remain a top down bureaucratic process, far removed from the concerns of citizens' (Eggers and Singh, 2009, p3) - 'there is no going back to the all knowing, all encompassing role of the government in the context of welfare states' (Bourgon, 2008).

\section{THE AUSTRALIAN PUBLIC SECTOR}

The Australian public sector is a regulated, non profit making service provided by government for its citizens either directly or indirectly through financing the private provision of services. The Australian Government Public Service Act No. 147 of 1999 (as amended) provides public servants with a work and risk ethic where regulations specify requirements to achieve a goal (Love, Niedzweicki, Bullen and Edwards, 2012). Such regulation provides a safe secure work environment but one which may dampen the need to be innovative to have a successful career. Public servants are not subjected to the same drivers as the private sector. To survive in the private sector there is a need to be competitive and profitable, to market product (goods or services) to achieve sales, and to maintain/improve reputation. The Australian private and public sector cultures and industries are very different from each other. While 'the alliance approach has a successful track record in Australia' in reducing these tensions, there remain a number of 'common criticisms of alliances’ yet to be addressed (Hennevald, 2006 pps 5-7).

\section{RESEARCH QUESTION}

Indicative of the current state of the industry is that 'poor quality tender documents continue to be a source of inaccurate estimates, claims and disputes' (Laryea, 2011 
pps 275-286) and 'few industries suffer more from conflict than construction' (Black et al, 2000). While Australian public sector owners aim to achieve 'value for money', contractors aim to optimize profit and improve reputation. These differing aims cause much conflict. This research frames how these differing aims could be better achieved and this may in due course influence construction industry theory and practice.

\section{4. 'VALUE FOR MONEY'}

The University of Cambridge (2010), the Higher Education Funding Council for England (HEFCE) describes 'value for money' as a term used to assess whether or not an organisation has obtained the maximum benefit from the goods and services it both acquires and provides, within the resources available to it. Some elements may be subjective, difficult to measure, intangible or misunderstood. Judgement is therefore required when considering whether 'value for money' has been satisfactorily achieved or not. 'Value for money' not only measures the cost of goods and services, but also takes account of the mix of quality, cost, resource use, fitness for purpose, timeliness, and convenience to judge whether or not, together, they constitute good value (Harvey, 2004 - 2012). For the public sector, the notion of accountability is central to defining quality with accountability being based on the need for restraint in public expenditure (Lomas, 2002). 'Value for money' is often linked to efficiency where efficiency is the extent to which an activity achieves its goal while minimising resource usage. For the private sector, 'value for money' sees quality in terms of return on investment - if the same outcome can be achieved at a lower cost, or a better outcome can be achieved at the same cost, then the customer has a quality product or service (Harvey \& Green, 1993). For both, 'value for money' assesses the cost of a product or service against the quality of provision (Harvey, 2004-12). Prior to the completion of a contract, it is difficult to demonstrate value for money as there are 'no universal objective measures of value' (Hennevald, 2006 p6).

\section{PLANNING COMMENCES WITH PROJECT 'OWNER'}

'Poor scope definition is recognized by industry practitioners as one of the leading causes of project failure, adversely affecting projects in the areas of cost, schedule, and operational characteristics. Unfortunately, many (owners) do a poor job of adequately defining a project's scope leading to a poor design basis' (Cho and Gibson Jr, 2001 p115). Adequate and timely preconstruction planning is essential for the successful delivery of projects (Hwang and Ho, 2012 p567). Such planning commences with the project 'owner', not with the construction industry. A project 'owner' is defined as the organization responsible for commissioning and financing a project (Barlow, 2000). The effectiveness of (an owner's) front-end planning will profoundly affect project cost and schedule performance as well as the overall success of a project (Gibson and Hamilton 1994). While project planning provides a common reference point that serves as a basis for project monitoring, control, and corrective action (Rosenau and Githens 2005), it is necessary for construction industry professionals to understand the (owner's) needs prior to any project commencement (Hwang and Ho, 2012 p567). But the resources an owner allocates to the conceptual planning stage are often well intentioned but inadequate or inappropriate. Well prior to the start of a construction industry project it is 
necessary for an owner to develop a vision of its future and the capabilities it needs to implement that vision. These are usually expressed in the form of a capability brief/business case. This is a challenging process for owners. It is an owner's capability planning investment that will reap subsequent benefits and which precedes the construction industry's design, development, tendering, contract and completion processes.

\section{PUBLIC SECTOR CAPABILITY BRIEF DEVELOPMENT}

Cooke-Davies and Arzymanow (2002 p 471) found that 'the most highly developed project management models are in the petrochemical and defence industries'. This suggests the project management models of the Australian Department of Defence would be representative of and demonstrate good public sector construction engineering and management procurement processes in Australia.

Typically, the Australian Department of Defence capability development process begins well before project entry into the defence ten year capability plan (Australian Government, 2006), that is, the defence 'project portfolio' (Jonas 2010, p818). It begins with identification of the need to address defence capability gaps. This need is progressively translated into business case options derived from government strategic guidance, current and future defence operational concepts and technology, emerging environmental issues, and already identified defence capability requirements. Drafts will be circulated by the Defence Capability Group for comment and are transformed progressively into a costed, defined capability brief with business case options to be considered by the appropriate defence executives and committees. The preferred business case option is identified and given a schedule for procurement and budgetary provision for acquisition and through life costs (Australian Government, 2006 pps 98-101). The capability brief/business case is expressed in defence 'core' business terms, not those of other industries. The role of the Capability Development Group is to develop and gain government approval for future defence capabilities and is responsible, as sponsor, for developing capability proposals, consistent with strategic priorities, funding guidance, legislation and policy, for consideration and approval by Government (Australian Government, 2012a). The Capability Development Group has a close relationship with the Defence Science and Technology and the Defence Materiel Organisations and oversees the implementation of the Defence Procurement Review recommendations. A Department of Defence (579 page) Procurement Policy Manual has been 'prepared for the guidance of Defence staff involved in procurement activities' (Gumley, 2009). But this Manual (Australian Government, 2006) defines no role for the involvement of industry in the development of defence capability, yet Defence expects industry to know and act upon the content of these documents.

For example, the Royal Australian Navy's (RAN) strategic acquisition of an improved underwater capability was expressed in the form a number of options, the preferred option being a conventional submarine. The option endorsed was for the capability to be built in Adelaide, home based in Sydney and able to be docked, repaired and maintained in Adelaide, Sydney and Western Australia. This outcome took defence more than five years of intense research and development. The significant construction aspects of this replacement defence capability were a 'green 
field' manufacturing site in Adelaide, renewed home base facilities in Sydney and new facilities in Western Australia at HMAS Stirling. Each of these facilities was scoped and programmed to fit with other time parameters and thoroughly costed. The AU\$ 6.5bn submarine project was approved for acquisition by government with a phased spend over more than eight financial years, each year with its own specific requirements. All proposed pre and post major contract variations were subjected to significant review internally, publicly, and subsequently by the Australian National Audit Office. The facilities aspects of this new capability were scoped, priced and timetabled to meet other submarine manufacturing requirements, and were initially expressed in defence capability terms, not in the language of the construction industry. These were then used by defence to develop 'design briefs' for the construction industry.

\section{THE PUBLIC SECTOR OWNER'S PERSPECTIVE}

A 'design brief' may be defined as '.... a set of instructions about what a new product should look like or what features it should have.' (Financial Times, 2012). Traditionally the 'design brief' and not the owner's capability brief/business case is the vehicle used to communicate a public sector owner's requirements to the construction industry. This means that much of the argument, input and discussion from the many and varied broad base of defence stakeholders is not communicated either selectively or publicly to the marketplace. This in turn limits both defence and industry design team decision making and collaborative efficiency, the ability to achieve clear team goal/objectives and design competitive advantage for innovation (Yin, Qin, and Holland 2011). The traditional Australian public sector pre-contract award stage requires the owner to define the design brief, select the tender model and method, check and sign off drawings, specifications and consistency with the government's requirements, check market conditions, confirm pre-tender estimates and key selection criteria. In the tender period, governments assemble and check the tender documents including contract conditions, drawings and specifications, bills of quantity, full documentation including detailed submissions of price and program, advertisement arrangements and tender closing details. The tender stage requires a tentative timed program from tenderers, including the level of allowable delays and float time, and latent conditions considerations. The evaluation stage lists and records tenders, applies key selection criteria and weightings to conforming tenders, checks referees, negotiates variations such as options, re-confirms the budget and recommends the preferred tenderer. The contract stage includes discussions and negotiations with tenderers concerning contract variations, tradeoffs, options, budget confirmation and final vetting of the preferred tenderer for viability (Capital Projects and Service Planning, 2011). These are expensive and time consuming processes for both the public and private sectors (Thomson, 1995).

\section{PRE CONTRACT AWARD CONTRACTOR'S PERSPECTIVE}

From a contractor's perspective, everything must be properly planned, coordinated and controlled if a tender of adequate quality is to be delivered (Lock, 2007). But traditional public sector pre-contract award procurement policies and practices impose significant transaction costs and times on both the private and public sectors (Williamson, 1998). This was evidenced by a costs of tendering survey of 
companies doing more than AU\$1m annual business with defence. The survey was responded to by 81 of the 160 contractors approached. In summary the contractors sought simplification of defence project specifications; public timetabling of tender outcome advice; pre-qualification, evaluation and weightings advice of the assessment criteria; greater use of commercial arrangements and shortlisting; use of best commercial practices; and detailed information of the project cost estimates for each project (Thomson, 1994). However, most Australian government regulations still state that 'it is usual to accept the lowest conforming tender' and 'an indication of the scope and size of the project will be included in advertisements but any reference to the estimated value of the works will not be included' (Capital Projects and Service Planning, 2011 pps 2 and 5). Such regulation continues to emphasise tender selection based on lowest cost while paying lip service to 'value for money'.

\section{POST CONTRACT AWARD CONTRACTOR'S PERSPECTIVE}

Once awarded a contract, Lock (2007) suggests that contractors consider a project well delivered if the project finishes on time, to specification and budget. These three objectives are widely accepted by the construction industry as measures of project success, the underlying assumptions necessarily being that the project has been profitable and the Contractor hasn't lost reputation. They relate principally to the execution stages of a project, which is of most direct interest to a contractor. A project that is delivered on time, within budget and to specification may well but not necessarily provide the contractor with a good profit, beneficial publicity and satisfaction. But the public sector owner may find the project fails to meet its capability brief/business case requirements and is therefore a failure. The initial definition of requirements given in the public sector owner's capability brief/business case is where and when the foundation for success or failure is laid. Lock (2007) advises that contractors' common complaints include that a project's scope is not clearly stated or understood, technical requirements are vague, estimates of cost timescale or benefits are too optimistic, risk assessment is incomplete or flawed, the intended project strategy is inappropriate, insufficient regard is paid to cash flows and the provision of funds, the interests and concerns of industry stakeholders are not taken into account, undue regard is paid to the motivation and behaviour of people who will execute the project, insufficient thought is given to how all affected by the project will be motivated to adapt to the changes expected of them, or approval to proceed with the project is given for political personal or intuitive reasons without due consideration being given to industry. These problems originate with the public sector owner.

\section{INNOVATION: CAPABILITY BRIEF/BUSINESS CASE CONSTRUCTION INDUSTRY EXPERT ENGAGEMENT}

A government's capability brief/business case sets the scene for ultimate project success or failure. If the project is incorrectly or inadequately defined, or if the strategy and risk assessments are wrong, a poor result is inevitable. But the Australian public sector's development of its capability brief/business case is usually neither made accessible to industry nor involves industry. This exclusion makes it very difficult for industry to be informed of the public sector owner's business requirements, owner stakeholders, or to be of assistance in the translation of the 
public sector owner's capability brief/business case requirements into construction industry language, or to make available to the owner industry knowledge relevant to the development of the capability brief/business case. While government will usually expect translation of its needs from capability brief to design brief to be undertaken by an internal organization, even interested conscientious public servants find it difficult to keep up with the pace of change in the construction industry and associated technology. Other difficulties include public sector employees being posted for short term career development and therefore being inexperienced, and being protective of internal information (doctrina vim promovet). Lopez and Love (2012 p585) found that 'design errors can adversely influence project performance' but 'were found to not significantly vary with procurement method or project type used'. This suggests that design brief errors take place before the 'procurement method or project type' is selected, that is, during the development of the capability brief/business case.

Design adjustments taken at a later time are 'directly responsible for considerable costs driven by changes that could have been avoided emerging at later stages of a project. Late changes are far more costly and time consuming than when they are made early on in a project.' (Hwang and Ho, 2012). The 'ability to influence the final characteristics of a project's product is highest at the start of the project and decreases as the project progresses towards completion ... the cost of changes and correcting errors typically increases substantially as the project approaches completion' (PMI, 2008 p 17). Levitt and Mahalingam (2002) suggest that an owner's project planning ability to influence project outcomes falls rapidly once the project begins (the inverse of the cost S-curve) - when outcomes become known, all project funds have already been expended and no influence remains. The best public sector planners can hope for is to learn from a given project and to adapt this for future projects - even this is difficult, because project participants scatter at the end of a project, and their learnings get diffused.

Including industry experts early in the development process is likely to achieve improved needs definition so improving 'value for money' outcomes. This will give both public sector owner and industry a better understanding and definition of the price, period and quality implications of design decisions. This could be achieved by competitively selecting construction industry experts who are competent in both the public sector owner's business and in their project's area of the construction industry. There are many companies who could offer such expertise. This is likely to have better productivity outcomes than solely public servants fulfilling this role, which is currently the case. However, the employer of such expert(s) would not be permitted to bid for the contract or any subcontracts for reasons of conflict of interest and confidentiality. The contracted entity would need to sign a confidentiality agreement with the public sector owner.

\section{INNOVATION: FIXED COST (PRICE); FIXED TIME (PERIOD); AWARD BASED ON 'VALUE FOR MONEY'}

The Chan and Chan (2004) review of journals on project success revealed that cost (price), time (period) and quality ('value for money') (Atkinson's [1999] 'iron triangle') are the three most important performance indicators in projects, and so provide a 'focus on key success factors' (Clarke, 1999) 'to meet customers needs' 
(Ferrell \& Hartline, 2011). The purpose of the Barnes (2007) triangle of objectives was to illustrate that the three primary objectives of cost, time and quality are interrelated - greater emphasis on achieving one or two of these objectives may be made at the expense of the other criteria. Some argue that quality can be achieved without extra cost by engaging in the concept of 'zero defects'(Crosby, 1987 p4). But a definition of quality is that a service or good is 'fit for the purpose for which it was intended' (Juran \& Godfrey, 1999). So quality may not be negotiable, but cost and time may be. Alternatively, this may be expressed as what quality ('value for money') can be achieved by a contractor within a fixed cost and time, that is, conditions which provide for a Pareto-efficient development of public infrastructure, where Pareto optimality in this case refers to achieving better quality at the same cost. For example, suppose the cost and start and finish times were fixed for a new construction, and all tenderers were requested to competitively provide solutions within the specific fixed period and fixed price in response to a public sector owner's performance brief/business case. This would mean all tenderer's bids would be based on the same period and price, but quality ('value for money') would vary. Period and price would then be unnecessary as bid assessment criteria since all bids would be using the same fixed price and fixed period parameters. Focus for both tenderers and tender assessors would be solely concentrated on bid quality alone, that is, 'value for money'. This approach eliminates the need for contractors to submit a lean and mean price driven down by cost competition.

\section{INNOVATION: CONTRACT RISK ADJUSTMENT}

After the parties have entered into a contract, the construction phase of performance commences and is associated with contract management. Research in Sweden (Kadefors et al, 2004; Kadefors, 2004) indicates that during the construction phase there are often many specification/scope changes. As every construction project is unique, the drawings and specifications in the owner's approved contract documents seemingly will always contain errors and omissions that have to be corrected. Changes in public sector owner needs, market demand or government regulations will modify public sector owner preferences and lead to changes in requirements. This is in a contracting construct where currently an owner 'approves' specification of requirements (usually very detailed), drawings, contract changes and so on. But need this be the case? Perhaps the selected tenderer/contractor could accept increased risk and opportunity for innovation in exchange for the guaranteed payment arrangements Australian government contracts carry. Kadefors et al (2004) found that in Sweden, many owners shared the view that closer co-operation with contractors would be advantageous, but that there was a need to look for a better integration of design and construction, less conflict and more flexibility - that many owners were suspicious of contractors and were reluctant to abandon general contracts and their control of the design, and view co-operation as something that primarily benefits the contractors. Kadefors et al (2004) indicated that contractors for their part, have tried to persuade owners to use 'design and construct' contracts more frequently and to make such contracts less specific so that contractors may participate in the initial phases of a project.

Since the financial risk to contractors of not being paid for satisfactorily completed Australian government work is zero, it would seem an equitable and appropriate risk adjustment to move greater design and construction risk to contractors who are, in 
any case, better placed to carry such risks. In this context, the Australian Attorney General was requested to consider contract terms and conditions which would transfer greater risk to the Contractor and more equitably enable project scope variations. The Australian Attorney General suggested terms and conditions as follows:

'Acknowledgement': 'any inaccuracy or mistake however arising shall neither affect the contractor's obligation to complete the work under the contract nor entitle the contractor to payment of any extra moneys whatsoever';

'Acceptance' of drawings and specifications: 'after acceptance of the contractor's tender, the contractor shall expeditiously prepare and complete all other documentation';

Liability remains with the contractor until completion of the contract: 'No approval, direction or assistance given to the contractor in respect of specification or designs or other data produced shall relieve the contractor of responsibility under the contract for the correctness of all such designs, drawings, specifications and other data created or supplied for the purposes of the contract';

Warranty of sufficiency and fitness for purpose: 'the contractor warrants the sufficiency and fitness for its purpose of all designs, drawings, and specifications prepared pursuant to the contract for use in the execution of the work'; and

Variations cause or delay: 'the contractor shall not be entitled to claim from the Principal any damages, loss, loss or expense or extra costs incurred by the contractor in respect of cause or delay'.

These risk transfer and contract variation clauses suggest opportunity for innovative competitive tenders to be submitted, this in exchange for guaranteed payment for work satisfactorily completed. The effectiveness of this alignment provides for the owner to 'acknowledge' rather than 'approve' the tendered offer. Since no two tenders will be identical, each tenderer will need to be innovative in its offer in delivering value for money.

\section{METHODOLOGY}

The methodology for this research should not only be helpful and improve practice but also contribute to a theoretically and scientifically useful body of knowledge. For such frames to be achieved, 'it does not necessarily follow that theory leads practice' (Lawler, Mohrman, Mohrman, Ledford and Cummings, 1985 p5). 'The most useful research is that which takes a more fine-grained approach, the challenge being to extract from it some general conclusions, insights and frames that contribute to theory ... with the problem of gathering (empirical) data in such a way that it is replicable' (Lawler et al, 1985 p11). Durkheim (1952) applied induction by observing, describing and comparing, so providing a 'form of empirical evidence' achievable through the use of case studies (Blaikie 1993, p138). Gannon and Smith (2011 pps 186, 188) found that current business case practice had evolved from common practice on traditional procurement forms ... but this approach was a costly, ad hoc method of developing a business case and at worst was likely to lead to decision making based on inappropriate information (Yin, 2003 a,b; Soy, 2006). 
Phelps and Horman (2010, p58) suggest that 'traditional research methods have not enabled advances in understanding construction industry phenomenon', and that 'the methods are not adequate to enable understanding of the complex interactions leading to many of the industry's pervasive social and technical problems'. Further, Phelps and Horman (2010, p58) propose a need to 'complement quantitative and case study methodologies with qualitative theory-building methodologies and studies based on detailed and long term observations of the project environments'. The Phelps and Horman (2010, p58) paper identifies a critical need for theory building methods and methodological challenges. 'What has changed is the interpretation of the ideas and problems that confront the construction sector globally and the methodological pluralism approaches available to resolving them' (Hughes, 2007 piii). This research will take a pluralist methodology through the development of an artefact in the form of a construct, model or method and test a case using a fine grained approach over a lengthy period. From this some general conclusions, insights and frames may evolve which contribute to theory, and in doing so gather empirical data that is replicable.

\section{METHOD: AN ARTEFACT INCORPORATING INNOVATION}

This artefact will incorporate some innovations the early engagement of a construction industry expert to assist the owner with the development of the capability brief/ business case and further assist through all phases to contract completion; the fixing of the period and price and using these and the capability brief/business case to call tenders and award a contract; and the transfer of greater design and construction risk to a contractor. This model was agreed by defence to be tested through a RAN project. An expert would be competitively engaged to assist the RAN in the development of the capability brief/business case and thence through all processes to contract completion. Following the registration of interest process, the RAN with expert assistance would shortlist interested parties to the three to five best and request tender submission. Tenderer's bids would be required to contain all details such as drawings, specifications, program of work, progress payments, bills of quantity, timings and so on. Contract award would be based on 'best 'value for money' since price and period would be fixed for all tenders, that is, the best offer for the fixed price and fixed period. The contractor would implement its offer assisted as appropriate by the expert, who would liaise and moderate project development issues at the owner/contractor interface. The contractor would be paid by the RAN according to the contractor's programme for work satisfactorily completed. Negotiation of contract variations would be undertaken within the fixed price and fixed period limitations, assisted and moderated as necessary by the expert. The RAN with expert advice will manage, monitor and moderate the contractor through to contract completion, close off the contract and the defects liability period (Figure 1). 


\section{The Capability Brief Model}

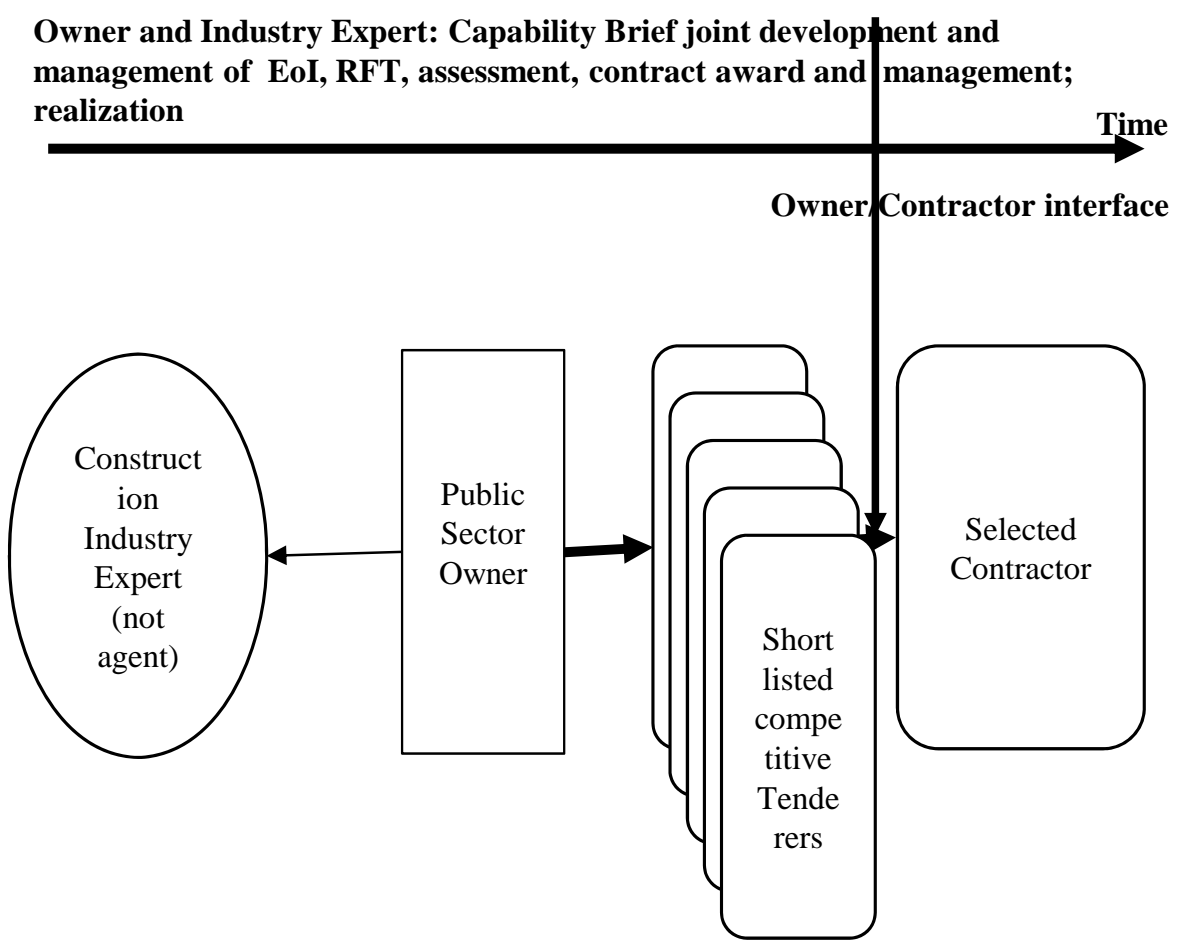

Figure 1: Innovative Australian public sector construction - effectively engaging the private sector

\section{INNOVATION IMPLEMENTATION: CASE STUDY}

Defence provided an accommodation facility for 24 Senior Non Commissioned and Warrant Officers at HMAS Cerberus, a RAN shore station in Victoria, Australia for the case study. Project period and price criteria were based on precedent defence 'design and construct' projects and Defence Scales and Standards of Accommodation. Based on these criteria, the project period and price were calculated by the expert (John Holland Group) to be a pre-contract award period of four months, a construct period of eight months, and an estimated price of AU\$0.891m. The four month pre-contract award period comprised the time taken from receipt of the capability brief/business case by the Defence Support Group from the Defence Capability Development Group, the development of the 'design brief' through all the regulated processes to contract award. The eight month post contract award period was the estimated time taken for construction of the project. Government Scales and Standards set specifications for floor areas, common use clothes washing and drying facilities, twin share bathroom and toilet, rudimentary paths and car-parking facilities, within a design to cost target of $\$ 27,500$ per person. The $\$ 27,500$ per person included the cost of the specified building areas, desk, bed and wardrobe. In addition, an allowance of $10 \%$ ie $\$ 2,700$ per person was permitted 
for specified non fixed furniture, fittings and equipment, and an additional allowance of $25 \%$ ie $\$ 6,875$ per person for the balance of all other works. These data provide the basis for value for money comparisons to be made with design and construct.

\section{TESTING THE ARTEFACT}

For the artefact, the price (AU\$891,000) and period were fixed (four months for preparation and 8 months for construction), and the capability brief/business case set the criteria to be met by industry. This comprised a capability brief of seven pages which expressed the owner's performance requirements. This brief became an annex to the General Conditions of Contract which included AAG's contract clauses. Tenderers were required to competitively provide a set of design drawings and documentation sufficient to accurately define and quantify the project, including a statement substantiating the design, a location/site plan, floor plans and matching elevations and sections, finishes schedule and materials specifications, a project delivery bar chart and resource schedule, cash flow chart, landscaping, life cycle costing and a fixed lump sum price with no rise or fall. The RAN then called for Expressions of Interest (EoI) using the fixed price (AU\$0.891m), fixed period (8 months), and seven page capability brief. 57 Expressions of Interest were received from the marketplace. These were shortlisted by the RAN and the expert to five companies on the basis of financial capacity; resource capacity; previous experience; designer's experience; sub-contractors; and insurance/indemnity strengths. Two of the five were global/national corporations, two were national/regional, and one was regional/local. The RAN then requested tenders from these five using the same capability brief, fixed period and fixed price. The five tenderers made post tender closure presentations to the RAN and the expert. Based on these competitive tenders and presentations, the selection of the 'best 'value for money' tender became quickly obvious, was not complicated by variations in period or price, or delayed by 'trade-offs' or contract negotiations. Assessment and award of the contract by the RAN with expert assistance took one day, including the tenderer's presentations. There were no appeals. This pre- contract award work was completed within two months. Once awarded the eight month AU\$891,000 contract, the selected contractor set to work without delay and completed within seven months.

Outcomes

Initially there was expressed disbelief from the tenderers that the RAN would stay with the fixed price and fixed period arrangement, as there had been no previous experience of such. None of the tenderers had concerns about the transfer of greater design and construction risk through the use of the Australian Attorney General contract clauses, or with any of the processes including the use of the industry expert once it was known that the expert would not be permitted to bid for the contract. The contractor completed the project one month ahead of time, to price, and to a much higher quality than that which would have been achieved had defence used its usual 'design and construct' contract method. Scope/quality benefits above that which would have been achieved using the standard 'design and construct' model included a motel style individual unit for each occupant with its own bathroom , toilet, washing machine, tumble dryer, bar fridge and tea making facilities, carpet, steam iron and ironing board, car wash and parking, all provided within the $\$ 891,000$ design to price target. The Contractor sought and was granted a contract variation to finish one month ahead of schedule. This suggests the conditions which 
provide for a Pareto-efficient development (Mathur, 1991) of public infrastructure were achieved, where Pareto optimality in this case refers to achieving better quality at the same cost. Further, competitive tenderer innovation was achieved through early engagement of a construction industry expert leading to improved expression of defence capability requirements; shortlisting through use of registration of interest; rapid tender evaluation and outcome advice; use of contract clauses which not only created greater owner transparency but also transferred increased design and construction risk to the construction industry thus encouraging greater innovation and responsibility from tenderers.

\section{CONCLUSIONS}

Heilman (2008) argues that public policy experimentation often means innovating through implementation first and drafting universal laws and regulations later. This is in direct contrast with standard assumptions about public policy making given that the 'conventional model of the policy process that is widely taken for granted ... holds that public policy analysis, formulation and embodiment in legislation precede implementation'. But 'an increased practice-led focus on public sector innovation within government suggests that practice has driven theory' (Mathews, Lewis and Cook, 2009 p2). This public policy project experimentation meant innovating through implementation first, with the possibility of the drafting of universal laws and regulations later.

In this context, the research addressed some of the enduring problems where 'poor quality tender documents continue to be a source of inaccurate estimates, claims and disputes' (Laryea, 2011 pps 275-286) and 'few industries suffer more from conflict than construction' (Black et al, 2000). In this case, the Australian public sector owner achieved better 'value for money' than it had previously when using its traditional 'design and construct' model with no disputes, extensions of time or increased costs. The early engagement of an industry expert provided assistance not only in establishing and maintaining good relationships, but also in the management of the contract and moderation of scope changes and other issues through to contract completion. Tenderers were able to reduce their costs of tendering and were motivated to submit competitive innovative proposals largely because they were given firm fixed period and price information and a seven page owner's performance requirements, and not the usual detailed specifications of most owners. This process enabled a quick turn around of tender development, assessment and outcome since there were far fewer variables to be considered by the owner, the period and price being fixed. Post contract award, the Contractor, completely familiar with its own submission and not having to interpret someone else's or be other than clinical in relationship maintenance, completed one month early thereby gaining additional profitability and improved reputation. It is suggested this method, underpinned by legal agreement, is less dependent on relationship management than PPP/PFI or alliance contracting and so be more globally applicable.

\section{FUTURE DEVELOPMENT}

Future research will involve undertaking further case studies to test the efficacy of the capability brief/business case model's applications in the global construction 
industry. The capability brief/business case model is generic in nature and in time may be applied to other industries. 


\section{REFERENCES:}

Atkinson, R., (1999), Project management: cost, time and quality, two best guesses and a phenomenon, its time to accept other success criteria, International Journal of Project Management, 176 337-342;

Australian Government, (2012a), Capability Development Group, Department of Defence, Canberra;

Australian Government, (2012b), Defence Support Group, Department of Defence, Canberra;

Australian Government, (2011), Commonwealth Procurement Guidelines, Department of Finance and Deregulation', Canberra;

Australian Government, (2006), Defence Capability Development Manual, Department of Defence, Defence Publishing Service, Canberra;

Australian Government (2003), Defence Capability Plan 2004 - 2014 Public Version, Industry Division of the Defence Materiel Organization, Defence Publishing Service, DPS:NOV16/03

Barnes, M., (2007), Project Management, PMBOK, Gower Publishing, UK;

Barlow, J. (2000). "Innovation and learning in complex offshore construction projects.” Research policy, 29(7-8), 973-989.

Black, C., Akintoye, A., and Fitzgerald, E., (2000), An analysis of success factors and benefits of partnering in construction, International Journal of Project Management, 18 423-434;

Blakie, N., (1993, Approaches to social enquiry, Polity, Cambridge;

Blayse, A., and Manley, K. (2004). "Key influences on construction innovation.” Journal of Construction Innovation, 4(3), 143-154;

Bourgon, J. (2008). 'The Future of Public Service: A Search for a New Balance', (Keynote Address to the 2008 IPAA National Conference Speech), Australian Journal of Public Administration, Vol. 67, Issue 4,

pp. 390-404;

Capital Projects and Service Planning, (2011), Methods of Tendering, Department of Health, State Government of Victoria, Melbourne, Australia;

Chan, APC., and Chan, APL., (2004), Key performance indicators for measuring construction success', Benchmarking: An International Journal, Vol 11, No 2, Emerald Publishing;

Cho, CS and Gibson Jr, GE., (2001), Building project scope definition using project definition rating index, Journal of Architectural Engineering, Vol. 7, No. 4, December;

Clarke, A., (1999), A practical use of key success factors to improve the effectiveness of project management, International Journal of Project Management, 173 139-145;

Cooke-Davies, TJ., and Arzymanow, A., (2003), The maturity of project management in different industries: an investigation into variations between project management models, International Journal of Project Management, 21 471-478;

Crosby, PB., (1987), The changing of quality in America, Winter Park Public Library, FL, USA;

Das, TK., and Teng, B-S., (1998), Between Trust and Control: Developing confidence in partner co-operation in alliances, Academy of Management Review Vol 23, 401-512;

Durkheim, E., (1952 [1897] Suicide, Oxford University Press, Oxford; 
Eggers, WD. and Singh, SK., (2009), The Public Innovator's Playbook: Nurturing bold ideas in government, Harvard Kennedy School: Ash Institute for Democratic Governance and Innovation, USA;

Financial Times, (2012), Lexicon, The Financial Times Ltd 2012;

Ferrell, OC., and Hartline, MD., (2011, Marketing Strategy, $5^{\text {th }}$ Ed, South Western Cengage Learning;

Gambatese, JA., and Hallowell, M., (2011a), Enabling and measuring innovation in the construction industry, Construction Management and Economics, June;

Gambatese, JA., and Hallowell, M., (2011b), Factors that influence the development and diffusion of technical innovations in the construction industry', Construction Management and Economics, June;

Gann, D. M., Wang, Y., and Hawkins, R. (1998). "Do regulations encourage innovation? The case of energy efficiency in housing.” Build. Res. Inf., 26(5), 280296;

Gannon, MJ., and Smith, NJ., (2011), An effective outline business case to facilitate successful decision making', Construction Management and Economics, 29, 185197, February;

Gibson, G. E., and Hamilton, M. R. (1994), Analysis of pre-project planning effort and success variables for capital facility projects, Rep. Prepared for Construction Industry Institute, University of Texas at Austin, Austin, Texas USA;

Graham, D and Bachmann, T., (2004) Ideation: The Birth and Death of Ideas. John Wiley and Sons Inc.

Green, K., and Randles, S., (2006), Industrial ecology and spaces of innovation, Edward Elgar Publishing, Cheltenham, UK;

Griffith, AF., and Gibson Jr., GE., (2001), Alignment during pre-project planning, Journal of Management in Engineering 17:69-76;

Gumley, SJ., (2009), Defence Procurement Policy Manual, Department of Defence, Canberra;

Harvey, L., (2004-12, Analytic Quality Glossary, Quality Research International;

Harvey, L. and Green, D., (1993), Defining quality, Assessment and Evaluation in Higher Education, 18(1). pp. 9-34;

Hennevald, M., 2006, Alliance Contracting Removing the Boundaries for Infrastructure Delivery', Annual Conference of the Transport Association of Canada, Charlottetown, Canada;

Heilmann, S. (2008). 'Policy Experimentation in China’s Economic Rise', Studies in Comparative International Development, Vol. 43, No. 1, pp. 1-26.

Hughes, W., (2007, 'Past, present and future', CME 25 Conference: Construction Management and Economics, Volume 1, University of Reading, UK;

Hwang, B-G., and Ho, JW., (2012), Front end planning implementation in Singapore: status, importance, and impact, Journal of Construction Engineering and Management, 138: 567-573;

Jonas, D, (2010), Empowering project portfolio managers: How management involvement impacts project portfolio management performance', International Journal of Project Management, 28: 818-831;

Juran, JM., and Godfrey, AB., (1999), Quality Handbook (5th Edition), McGrawHill;

Kadefors, A, Gerle, C., and Nyberg, L., (2004), Trust and distrust in temporary public sector owner-contractor relations', Department of Service Management, Chalmers University of Technology, Goteborg, Sweden;

Klan, A., (2010), Managers are charging four times the norm for BER projects, The Australian, May 31; 
Kloppenborg, TJ., (2012), Contemporary Project Management, 2e, South Western Cengage Learning, OH, USA;

Laryea, S., (2011), Quality of tender documents: case studies from the UK, Construction Management and Economics, 29, March;

Levitt, RE., and Mahalingam, A, (2002), Predicting and Mitigating Instututional Costs in Global Projects; Department of Civil and Environmental Engineering, Stanford University, USA.

Lock, D., (2007, Project Management, $9^{\text {th }}$ ed, Gower Publishing Ltd;

Lomas, L. (2002) 'Does the development of mass education necessarily mean the end of quality?', Quality in Higher Education 8(1).

Lopez, R. and Love, P. (2012). "Design Error Costs in Construction Projects.” J. Constr. Eng. Manage., 138(5), 585-593. doi: 10.1061/(ASCE)CO.19437862.0000454

Love, PED., Niedzweicki, M., Bullen, PA., and Edwards, DJ., (2012), Achieving the green building council of Australia's world leadership rating in an office building in Perth, Journal of Construction Engineering and Management, 138:652-660;

Mathews, M., Lewis, C., and Cook, G., (2009), Public sector innovation: a review of the literature, Australian National Audit Office, Canberra, ACT;

Mathur, VK., (1991),How Well Do We Know Pareto Optimality? Journal of Economic Education, 22, No2 pp 172-178

OECD (2008), Public-Private Partnerships: In Pursuit of Risk Sharing and Value for Money, OECD Publishing, Paris.

Phelps, AF., and Horman, MJ., (2010), Ethnographic Theory-Building Research in Construction, Journal of Construction Engineering Management, 136, 58;

Project Management Institute, (2008), A Guide to the Project Management Body of Knowledge (PMBOK) $4^{\text {th }}$ Edition, Project Management Institute, PA, USA;

Queensland Government, (2008), Public Private Partnerships Guidance Material Supporting Document 'value for money' Framework, Department of Infrastructure and Planning, Brisbane, Queensland;

Rosenau, MD., and Githens, GD., (2005), Successful Project Management: A Stepby-Step Approach with Practical Examples $4^{\text {th }}$ ed, John Wiley, NJ, USA;

Soy, SK., (2006). The case study as a research method, University of Texas at Austin;

State Government of Victoria (2011), 'Tendering, Evaluation and Acceptance', Capital Projects and Service Planning, Department of Health

Thomson, JD., (1994), Costs of tendering industry survey, Department of Defence, Australian Government Publishing Service, Canberra, Australia;

Thomson, JD., (1995), Defence procurement delivery best practice and benchmark options, Department of Defence, Australian Government Publishing Service, Canberra, Australia;

UK NAO (2011) Lessons from PFI and other projects, Report by the Comptroller and Auditor general, HC 920 Session 2010-2012, 28 April;

University of Cambridge, (2010), A Brief Guide to Value for Money (summarised from HEFCE website) available at http://www.admin.cam.ac.uk/offices/secretariat/vfm/guide.html, accessed 29 June 2012

US Defense Contract Management Agency, (2012), Types of Contracts/Instruments, US Defense Contract Management Agency, Washington, DC;

US GAO, (2010), Defense Contracting: Enhanced Training Could Strengthen DOD’s Best Value Tradeoff Decisions, Report to Congressional Committees, GAO11-8, October; 
Williamson, OE., (1998), Transaction Cost Economics: How It Works; Where It Is Headed, De Economist 146, No. 1;

Wright, JN., (1997), Time and budget: the twin imperatives of a project sponsor, International Journal of Project Management, 15(3), 181-186;

Yin, Y., Qin, S., Holland, R., (2011), Development of a design performance measurement matrix for improving collaborative design during a design process, International Journal of Productivity and Performance Management, Vol. 60 Iss: 2, pp. 152 - 184

Yin, RK., (2003a), Case Study Research Design and Methods, $3^{\text {rd }}$ Edition, Sage Publications, CA;

Yin, RK., (2003b), Applications of Case Study Research $2^{\text {nd }}$ Edition, Sage Publications, California; 